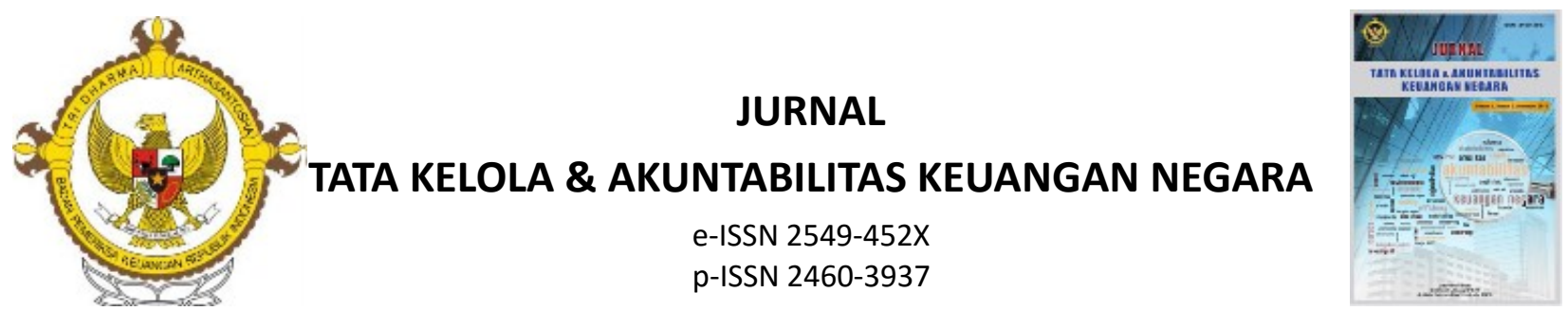

\title{
FACTORS AFFECTING INTENTION ON WHISTLEBLOWING: AN ANALYSIS ON MODERATED MODEL OF WHISTLEBLOWING CHANNEL
}

\author{
Astia Putriana $^{1}$, Bambang Hariadi ${ }^{2}$, and Yeney Widya Prihatiningtias ${ }^{3}$ \\ Universitas Brawijaya \\ Jalan Veteran, Ketawanggede, Lowokwaru, Malang, Jawa Timur 65145 \\ tia.putriana@gmail.com ${ }^{1}$ \\ hariadimadura@yahoo.com² \\ yeneyprihatiningtias@gmail.com ${ }^{3}$
}

\begin{abstract}
The purpose of this study is to examine and provide empirical evidence of the effect of personal responsibility, personal cost and education on whistleblowing intention, as well as the impact of whistleblowing channel in influencing personal cost on whistleblowing intention. The populations of this study are civil servants (ASN) from financial department and procurement services department in Banjarmasin Municipal Government. The sample of this study are 104 respondents, obtained using saturated sampling technique. Questionnaire data of this study is analyzed using the Partial Least Squares (PLS). The result shows that civil servants consider their personal responsibility as they intend to blow the whistle. Yet, the study finds that personal cost and education have no effect on civil servant's whistleblowing intention. The study also finds that whistleblowing channel is unable to moderate the effect of personal cost on whistleblowing intention. These findings help to obtain an insight regarding the policy that can improve whistleblowing intention.
\end{abstract}

\section{KEY WORDS:}

personal responsibility; personal cost; whistleblowing channel; intention on whistleblowing 


\section{INTRODUCTION}

The prevalence of fraud occurring all over the world, whether in the business or public sectors, have further garnered organization towards placing a better focus on the efforts of not only answering and dealing with every occurrence, but also to detect and prevent any fraudulent practices (Nurhidayat \& Kusumasari, 2018). Indonesia is a nation which places a great deal of attention towards cases of fraud. This is due to the results founded in a survey conducted by Transparency International Indonesia in 2016 that places Indonesia as the 9oth most corrupt country, among 176 countries.

The government have been continuously implementing various attempts in order to intensify their efforts in preventing fraudulent practices. Several efforts include internal control, establishing good governance, and even various technical mechanisms related to state administration which are free from corruption, collusion and nepotism (Sina, 2008; Widyastuti, 2015; Meikhati \& Rahayu, 2015). Preventive efforts have been further focused on encouraging whistleblowers as the main means that most effective in preventing fraudulent practices in the governmental sector, which happens to be the sector suffering the most from fraudulent practices (ACFE, 2016). Brewer and Selden (1998) discovered through their research that whistleblowing is very useful in stimulating substantial changes and facilitating reforms within the government.

Basri et al. (2017) realized that whistleblowing may minimize acts of fraud and prevent all the problems and losses associated with fraud. Furthermore, whistleblowing may also boost employee morale, work efficiency and also minimize the negative stigma surrounding an organization (Nurhidayat \& Kusumasari, 2018). Unfortunately, the reality shows that this is not proportionate towards the number of individuals intention to report cases of fraud. Meng and Fook (2011) found that people were still fearful and thus resisted the urge to report acts of fraud. The National Committee on Governance Policy, in a publicized note stated that a total of $52 \%$ or even more of employees were aware of violations being committed but are reluctant to report these incidents (Semendawai et al., 2011). This means that employee awareness in reporting acts of fraud is still considered very low and thus are in need to be strengthened in order to be capable of preventing further and larger losses caused by acts of fraud.

The low number of participation in whistleblowing is unsurprising, especially when there is no clear law ground that regulates one's obligation to report in acts of fraud. Existing legislation in Indonesia only regulates matters on witness and victim protection stated in Law Number 13 Year 2006 (Suratno, 2017). This is why there are still many factors which hinder those willing to report acts of fraud. This is also why it is very important to pinpoint and promote what may urge an individual to do whistleblowing action voluntarily.

There are still numerous other researches on the intention on whistleblowing (Ayers \& Kaplan, 2005; Septianti, 2013; Hakim, 2017; and Alleyne et al., 2017). Variables which have been frequently studied include personal responsibility according to the Graham Model (1986). Education on whistleblowing is also a variable that is more intensely studied (Ghani et al., 2013; Cho \& Song, 2015; Caillier, 2017). Results from previous studies still show inconsistencies in the results. Thus motivating researchers to examine the influence of personal responsibility, personal cost and education on the intention on whistleblowing. Aside from that, this study wishes to test moderator variables assumed to being the 
causes behind the inconsistencies found in previous studies, which are the reporting channels. This is urgent due to the enhancement of government in eradicating and preventing acts of fraud by implementing an anonymous reporting channel via website.

\section{THEORETICAL REVIEW}

This study utilizes the prosocial theory, the social learning theory and the utilitarian ethics theory as its basic. All three theories are relevant in the context of whistleblowing due to their capability in covering the individual, situational and organizational aspects affecting one's intention to become a whistleblower. The prosocial theory rises from the perception that every individual is inherently supportive towards acts which are an improvement and benefit society, such as whistleblowing (Eisenberg \& Mussen, 1989). But surprisingly, this social act is not always automatically identified as an altruistic act which serves the interests of the many over one's personal interests, but must also be put under consideration in relation to the selfishness of humans (Leeds, 1963). These factors include personal responsibility and risks benefits (personal cost) associated to whistleblowing (Graham, 1986; Schultz, 1993; Septianti, 2013; Hakim, 2017). These variables are the individual and situational factors which influence one's intentions to become a whistleblower (Hakim, 2017)

Alleyne et al., (2017), by using the Graham Model perfected by Schultz (1993) as their basic, examined factors influencing the whistleblowing behavior of accounting employees in Barbados. Results show that individuals wished to become whistleblowers when they realized that it was their responsibility. Furthermore, the thought of retaliation from those they report is a main obstacle for one intending to become a whistleblower. Hakim (2017) also conducted a similar research by examining the influence of personal costs on the intention of Tax Services employees in the North Malang and Kepanjen area to become whistleblowers. Results showed that personal costs did not prove to be a significant influence on their intention to report acts of fraud. Septianti (2013) also found similar results when examining employees of Indonesian Transaction Reporting and Analysis Center (PPATK) and the possibility of their intention to become whistleblowers, and found that personal costs did not affect their intentions.

The social learning theory is also relevance to be utilized as a basic for this study. This is due to this theory, first initiated by Bandura (1971), stating that an individual's actions are influenced by the process of learning, whether by observation or direct experience. Bandura (1971) states that each individual is an agent of change, fully participating in their environment and also influencing their environment and thus also influence the individual. The presence of education on whistleblowing within organizations portrays the presence of interaction between the individual and organizational environment. The individual would observe the environment as an inseparable part of themselves has stimulated for the creation of a workplace environment which is both ethical and free from acts of fraud, and thus further push others to become whistleblowers. This is the organizational factor which may influence the intention to become whistleblowers (Cho \& Song, 2015). Cho and Song (2015) conducted a study on civil servants from the federal government of the United States of America and discovered that education on whistleblowing proved to increase one's intention to do whistleblowing action. The latest research conducted by Caillier (2017) also presented similar results showing that one's intention to become a 
whistleblower increases when one thoroughly understands the act of whistleblowing.

The utilitarian ethics theory is also a basic of this study. This is due to, according to Cavanagh et al. (1981), the political behavior of individuals as being ethical, and thus whistleblowing as being one of them is the result of a utilitarian calculation as the best method to produce the best results. One would always strongly consider the best choice of action in order to optimize satisfaction and avoid the serious consequences from a certain political act, which must also include the channel to report the act. This too is the situational factor which may influence one's intention to become a whistleblower (Gao et al., 2015).

One will tend to choose a reporting channel capable of reducing every possibility of retaliation. Gao et al. (2015) discovered that the intention to do whistleblowing action increases when the reporting channel is managed by an external party, rather than by an internal party. This too is in line with the results from a study by Kaplan et al. (2012) which states that the reporting channel may become a predictor or moderator variable.

\section{The Effects of Personal Responsibility On The Intention To Do Whistle- blowing}

In line with the prosocial theory, personal responsibility is one of the factors considered when doing whistleblowing action as form of a prosocial act (Dozier \& Miceli, 1985). Personal responsibility refers to individual consideration to report on violations influenced by the sense of personal responsibility over co-workers, profession or organization colleague (Graham, 1986). Individuals will basically evaluate the size of the responsibility of reporting in acts of fraud that they are aware of, and thus influence whether to become a whistleblower (Miceli et al., 1991).

The effects of the diffusion of responsibility often result in individuals rejecting to conduct certain prosocial acts due to perceiving such acts can be conducted by others, not only their personal responsibility (Batson, 2011). Because of this, there is an urgency to evaluate the level of responsibility become urgent because it' is expected to have an effect on the effectiveness of whistleblowing (Gao \& Brink, 2017). An evaluation on personal responsibility is often associated to one's organizational role (Schultz et al., 1993) and sense of moral obligation (Curtis, 2006). Ayers and Kaplan (2005) explain that organizational roles are influenced by one's organizational commitment, whereas the sense of moral obligation is influenced by each individual's moral sense on what is right and wrong. Any individual that considers the act of whistleblowing as their own responsibility in order to save and protect the company will be inclined to become a whistleblower. Whereas on the other hand, one who considers the act of whistleblowing as not being a part of their responsibility will be inclined to remain silent.

Ayers and Kaplan (2005) also Robinson et al. (2012) discovered that personal responsibilities as being one of factors put into consideration before one becomes a whistleblower. Alleyne et al. (2017) carried out a research in Barbados and found results showing that personal responsibility clearly does influence an accountants intention to do whistleblowing action. Thus making reach the first hypothesis as follows:

H1: Personal responsibility positively influences the intention of civil servants to do whistleblowing action. 
The Effect of Personal Cost On The Intention To Do Whistleblowing

The prosocial theory states that an individual is inherently supportive towards acts to repair and serve social interests (Batson, 2011). This is due to being strongly related to altruism (Leeds, 1963). But the prosocial theory stresses that the act of helping others is always accompanied by considerations of the benefits and risks likely to be received. This is what is commonly considered as personal cost (Schultz et al., 1993).

Personal cost is what an individual considers and weighs when reporting breaches or becoming a whistleblower, influenced by the possibilities of retaliation from those they report (Graham, 1986). These acts of retaliation are forms of revenge committed by those being reported of having conducting fraud, but also possess the capability of retaliating against the whistleblower, for example by intimidating, exclusion, dismissal, etc (Zhuang, 2003).

The fear of retaliation is a significant factor in influencing one's intention to report fraud (Iskandar \& Saragih, 2018). The decision to report fraud will always be a very risky decision (Bhal \& Dadhich, 2011). If the management's attitude towards whistleblowers proves to be dismissively ignorant, hostile and even resentful, then it will force individuals to reach the rationalization of becoming mere inactive observers. One who experiences a lower possibility for retaliation due to being a whistleblower will increase the probabilities for them to report fraud, whereas the higher possibility of retaliation against whistleblowers, the lower the chances for those to report instances of fraud (Kuncara et al., 2017).

Ayers and Kaplan (2005) also Alleyne et al., (2017) revealed that the consideration of personal cost became the rasionalization for someone to just be an observer. Those who also experience a larger possibility of suffering from retaliation will also tend to remain silent. Based on that, the second hypothesis is as follows:

H2: Personal cost negatively influences the intention of civil servants to do whistleblowing action.

\section{The Effects of Education On The Inten- tion To Do Whistleblowing}

Social learning theory states that one must study through a process of observation and direct experience (Bandura, 1971). The learning process will influence individuals to behave according to what they have observed. So too is the process for reporting acts of fraud. Basri et al. (2017) states that it is highly unlikely for an employee to report an act of fraud when they do not possess sufficient knowledge on whistleblowing. Cho and Song (2015) explain that knowledge of whistleblowing is obtained through an educational process which helps employees in observing and recognizing the support from their organizations. Thus the knowledge of whistleblowing will influence individuals to report fraud (Caillier, 2017).

Education is strongly connected with the process of learning, which is the process of obtaining knowledge, expertise, professional behavior, values, trust, emotion and feeling (Jarvis et al., 2003). Education in the form of ethical trainings which is part of ethical behavior is the solutions in dealing with the complex matters within an organization (Stead, Worrell, \& Stead, 1990). A demoralizing work environment may be prevented and employee awareness on acts of fraud may be increased when the organization intensely educates employees.

The presence of sufficient education in the form of socialization and trainings is deemed 
to be able to increase the intention of employees to do whistleblowing action (Sheler, 1981; Frisque \& Kolb, 2008, Cho \& Song, 2015). Cho and Song (2015) also stress on the existence of education as a roadmap for future whistleblowers to understand the reporting mechanisms if they find fraud. Park et al. (2008) also states that the different public preferences on being anonymous whistleblowers according to each country caused by the effectiveness of education and trainings on trans-cultural unethical practices. Cho and Song (2015) also Caillier (2017) revealed that education on whistleblowing strongly effect one's intention to become to do whistleblowing action. Sufficient knowledge on whistleblowing obtained through education will help employees in observing and understanding the support from their organizations, and thus further urge employees to take the decision of reporting in cases of fraud. Based on that, the third hypothesis is as follows:

H3 : Education positively influences civil servants to do whistleblowing.

\section{The Effect of Whistleblowing Chan- nels' Moderation On The Correlation Between Personal Cost And Intention To Do Whistleblowing Action}

The theory of utilitarian ethics states that individual willing to conduct a political act will thoroughly evaluate the possibilities in order to avoid any fatal consequences towards themselves and all those related (Cavanagh et al., 1981). One of the alternatives which must be put into consideration are the reporting channels (Park et al., 2008). The reporting channels must provides maximum benefit and minimum risks (Hakim, 2017).

Retaliation is a factor that has a correlation with the intention to report fraud (Mesmer-
Magnus \& Viswesvaran, 2005). Not all people in an organization would deem whistleblowing as an act of heroism; some would see as traitors (Hersh, 2002). Andrade (2015) even went on to say that most individuals in an organization consider employees who blow the whistle as people who are disloyal towards the organization.

Near and Miceli (2016) states that retaliation tends to correlate with lack of support from the managers or the working culture of the organization itself. As a consequence, individuals who find themselves facing this issue would report a fraud only if he or she is able to determine that a reporting channel is able to protect him or herself from possible retaliation. Conversely, a person would tend to remain quiet if he or she observes that the available reporting channels are not profitable enough to him/her in avoiding retaliation.

Gao et al. (2015) found that reporting channels can serve as moderation variables. Miceli and Near (1985) also Ayers and Kaplan (2005) in their studies have found that whistleblowers prefer to pursue an anonymous reporting channels, as they are seen to offer a greater assurance of security. People tend to report a fraud if they can correctly choose a reporting venue that minimizes the risk of retaliation directed towards them. Conversely, a person would tend to stay quiet if he or she observes that the available reporting channels cannot sufficiently reduce the possibility of retaliation. Based on this, hypotheses four can be stated as follows:

H4 : Reporting channels moderates the effect of personal cost on the intention of civil servants to do whistleblowing action.

Figure 1 illustrates the research model. 


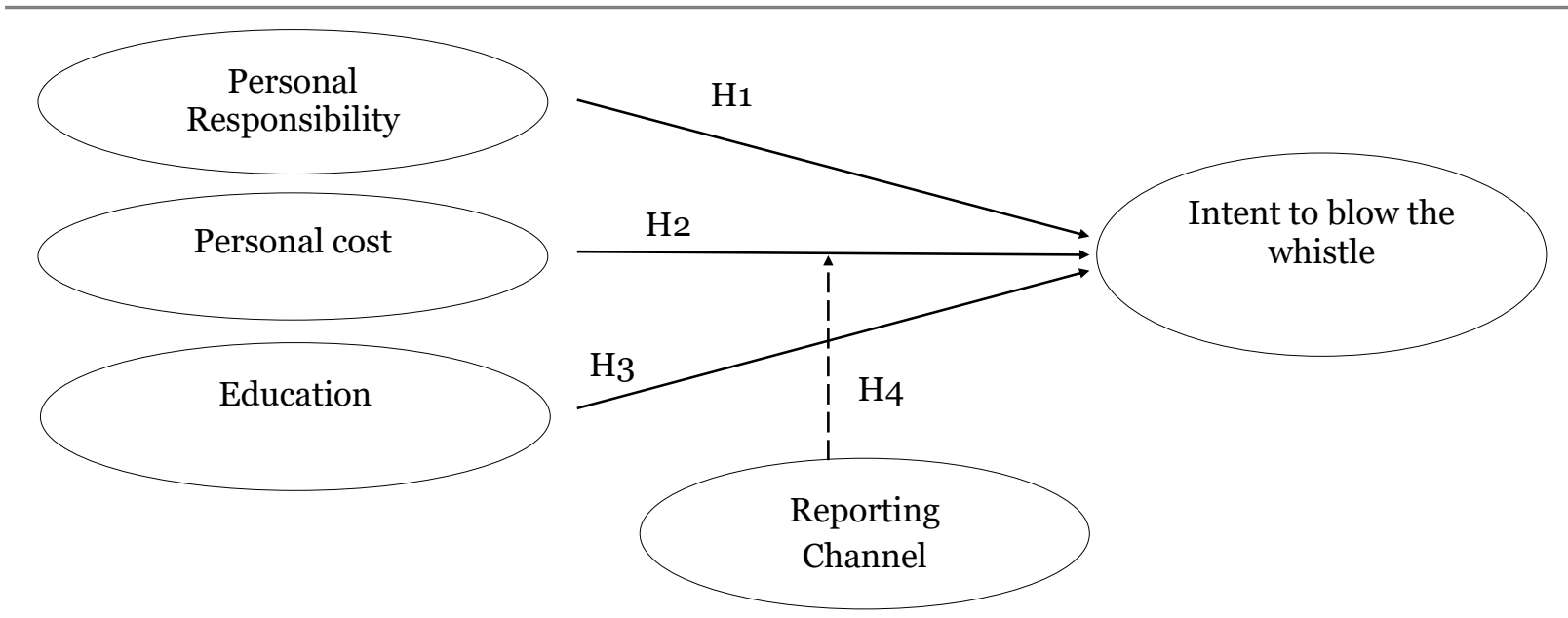

Figure 1. Research Model Source: Author's analysis

\section{RESEARCH METHOD}

This study is a quantitative research. A quantitative approach is used to test a theory by measuring variables using figures and analyzed using statistics.

\section{Research Population And Sample}

This study selects civil servants employed at the Local Government Agencies (Organisasi Perangkat Daerah - OPD) in the Banjarmasin Municipal Government as the research object and respondents. This selection is based on the grounds that: (1) based on the 2016 ACFE survey, the government is the sector most adversely affected by corruption; (2) the Banjarmasin Municipal Government is intensively solidifying the role of whistleblowers in identifying violations occurring within the Banjarmasin municipal government, as evidenced by the launching of a whistleblowing system application on the official website of the Banjarmasin government in 2016; and (3) data from the $\mathrm{Na}-$ tional Civil Service Agency (Badan Kepegawaian Nasional - BKN) obtained by KPK, the Indonesian anti-corruption body in 2018, shows that Banjarmasin is among the $14 \mathrm{mu}$ nicipalities that have the most civil servants involved in corruption.
The population of this study are 155 civil servants working within the financial units of the local government agencies and 23 civil servants in the Procurement Service Unit (ULP) working groups under the Banjarmasin municipal government. The selection of the financial units and ULP working groups was based on the fact that the financial and procurement units are two of the three administration areas that are most targeted for fraud (ACFE, 2016).

Selection of samples for this study employs a census or saturated sampling method, namely the use of all population as research sample. The reason is that the authors found it difficult to determine a definite quantity and valid population. However, during preliminary observation, the author received information that each of the local government units has on average 1 to 3 people working there, although some of these units is staffed by more than three people. As such, the author assumed that 40 local government units have civil servants working in the financial department and an additional 40 to 143 (23 people of ULP working group). Taking into account the opinion of Arikunto (2012), if the author finds that the quantity of research population may be less than 100, then preferably the sample is taken from the entire number of population. This measure 
was also influenced by the challenge found during earlier researches in collecting data, namely low response rate, while the author desires a high response rate to mitigate questionnaires that are unusable for the for the purpose of the research, such as due to not being filled out completely.

Data used in the quantitative approach of this study is primary data collected through questionnaires filled out by respondents. The data were collected using a survey technique using a self-administered method, whereby questionnaires were distributed directly to the respondents preceded by instructions on how to fill out the questionnaires (Hartono \& Abdillah, 2015). The data collection process occurred over a period from 21 June to 3 August 2018.

\section{Operating Definition And Measure- ment of Variable}

Intention on whistleblowing is defined as a person's tendency to be actually involved directly in the act of whistleblowing (Chiu, 2002). The measurement of the variable refers to the research by Septianti (2013) and Hakim (2017). The measuring of this variable uses three types of occupation fraud hypothetical cases developed by Septianti (2013) and adapted to the Indonesian context. Indicator of this variable is the likelihood of reporting financial fraud relating to reimbursement, bribery and corruption. The variable is observed by looking at the scores obtained from respondents relating to the probability of their involvement in whistleblowing of the three hypothetical cases.

Personal responsibility is defined as the psychological condition of a sense of responsibility to respond to principal problems related to work, social responsibility and severity of the problem (Graham, 1986). The measuring of this variable uses three types of occupational fraud hypothetical cases deve- loped by Septianti (2013) and adapted to the Indonesian context. Indicators for this variable are the different roles within an organization, namely treasury, senior staff at a goods/service procurement service unit, and senior internal audit staff. The variable is observed by looking at scores obtained from respondents relating to different roles within the organizations in the three hypothetical cases.

Personal cost is defined as a response received by an individual following implementation of an action (Graham, 1986). The measuring of this variable uses three types of occupational fraud hypothetical cases developed by Septianti (2013) and adapted to the Indonesian context. Indicators for this variable are retaliation in the form of postponement of promotion, removal from a goods/ service procurement unit, and threats of termination of employment or put in jail. The variables are observed by looking at the scores obtained from respondents relating to the severity of these three kinds of retaliation in the three hypothetical cases.

Education is a process by which knowledge, know-how, behavior, values, belief, emotion and feeling is acquired (Jarvis et al., 2003). The measurement of this variable uses an instrument developed by Cho and Song (2015). The variable has three indicators to facilitate measurement, namely knowledge of the purpose of internal control (inspectorate), availability of anonymous reporting channel, and rights as whistleblower.

Reporting channels are a range of alternative means to file reports by which a potential whistleblower can file a report on fraud (Park et al., 2008). The measurement of this variable refers to the research conducted by Park et al. (2008) that has been modified to conform to the Indonesian context by Hakim (2017). The authors also further modified the 
variable to suit the context of a municipal government. Reporting channels in this study is reporting channel that is implemented internally and anonymous in Local Government Agencies of the Banjarmasin Municipal Government. Internal reporting channel includes structural reporting channel such as superior, chief executive, and inspectorate. Anonymous reporting channels includes reporting channels via whistleblowing system which is implemented on Banjarmasin Municipal Government website that enables reporting using pseudonym and anonymous.

\section{Data Analysis Techniques}

The quantitative data analysis technique used in this study is the Partial Least Square (PLS) technique aided by the SmartPLS 3.0 program software. Reasons behind the use of the PLS method are because (1) the method is ideal for testing the predictive effect of the correlation among latent variables within the model; (2) PLS may be applied to data not distributed normally and the samples need not to be large; and (3) the results remain solid despite the occasional abnormal and missing data. Data analysis is done by: (1) observing and analyzing outer model feasibility; and (2) interpreting inner model data analysis results.

Hypothesis test is done by observing path coefficient scores with $5 \%$ significance. For hypothesis $\mathrm{H}_{1}$ to $\mathrm{H}_{3}$, if the t-statistic rates are $>1.64$ with the coefficient direction in line with the expected direction then the hypothesis is accepted, but if it is proven otherwise then the hypothesis is rejected. For hypothesis $\mathrm{H}_{4}$ with moderated variables, if the t-statistic rate is $>1.96$, then the hypothesis is accepted, but if it is proven otherwise then the hypothesis is rejected.

\section{RESULT AND DISCUSSION}

Data on respondents' profile, which includes sex, age, last education and length of service as civil servant, are presented in table 1. Table 1 shows that respondents who are female civil servants predominates, compared to their male counterparts. The above table also shows percentage by age of the respondents. Respondents older than 40 years old predominates. This demonstrates that the majority of respondents of the research working in the financial department and ULP working group are people of mature age.

Respondent participation by last education is predominated by those with Bachelor education (S1), followed by respondents with Diploma 3, high school, and Master degrees. There are no participants with a Doctoral degree in this study. Based on such composition, it can be concluded that bachelor degree holders predominates civil servants. Respondents of this study is predominated by people who have served as civil servants for more than 12 years, followed by those who served for 7-9 years.

The study conducts an outer model test prior to testing its hypotheses. The outer model test employs a convergent validity test, discriminant validity test and reliability test. Result of the test as presented in table 2 shows that the model has passed these various tests. The parameter used in the convergent validity test is a required factor loading value of greater than 0.7, AVE value of greater than 0.5 , and communality value of greater than 0.5 (Hartono \& Abdillah, 2015). However, Sholihin and Ratmono (2013) states that indicators that have a factor loading value of less than 0.4 must be removed from the model, while indicators with factor loading value between 0.4 and 0.7 are still acceptable. 
Table 1. Classification of Respondents' Profile

\begin{tabular}{|c|c|c|c|c|}
\hline No & Criteria & Description & $\begin{array}{c}\text { Number of } \\
\text { Respondents }\end{array}$ & Percentage (\%) \\
\hline \multirow[t]{4}{*}{1} & Sex & Male & 35 & 33.65 \\
\hline & & Female & 66 & 63.47 \\
\hline & & Not specified & 3 & 2.88 \\
\hline & Total & & 104 & \\
\hline \multirow[t]{7}{*}{2} & Age & $20-25$ years old & 0 & 0 \\
\hline & & $26-30$ years old & 8 & 7.69 \\
\hline & & $31-35$ years old & 34 & 32.69 \\
\hline & & $36-40$ years old & 21 & 20.19 \\
\hline & & $>40$ years old & 39 & 37.5 \\
\hline & & Not specified & 2 & 1.93 \\
\hline & Total & & 104 & \\
\hline \multirow[t]{7}{*}{3} & Last Education & Doctoral & 0 & 0 \\
\hline & & Master & 8 & 7.69 \\
\hline & & Bachelor & 42 & 40.38 \\
\hline & & Diploma 3 & 22 & 21.15 \\
\hline & & High school & 14 & 13.46 \\
\hline & & Not specified & 18 & 17.32 \\
\hline & Total & & 104 & \\
\hline \multirow[t]{7}{*}{4} & $\begin{array}{l}\text { Length of Service as Civil } \\
\text { Servant }\end{array}$ & $1-3$ years & 1 & 0.96 \\
\hline & & $4-6$ years & 3 & 2.88 \\
\hline & & $7-9$ years & 39 & 37.5 \\
\hline & & $10-12$ years & 15 & 14.42 \\
\hline & & $>12$ years & 44 & 42.31 \\
\hline & & Not specified & 2 & 1.92 \\
\hline & Total & & 104 & \\
\hline
\end{tabular}

Source: Author's data processing and analysis

Table 2. Result of Convergent Validity Test

\begin{tabular}{|c|c|c|c|c|c|}
\hline Variable & Indicators & $\begin{array}{l}\text { Factor } \\
\text { Loading }\end{array}$ & AVE & Communality & Description \\
\hline \multirow{3}{*}{$\begin{array}{l}\text { Education on Whis- } \\
\text { tleblowing (EW) }\end{array}$} & EW 1 & 0.780 & \multirow{3}{*}{0.678} & \multirow{3}{*}{0.678} & Valid \\
\hline & EW 2 & 0.813 & & & Valid \\
\hline & EW 3 & 0.874 & & & Valid \\
\hline \multirow{4}{*}{$\begin{array}{l}\text { Whistleblowing } \\
\text { Channel (WGC) }\end{array}$} & WGC 1 & 0.832 & \multirow{4}{*}{0.549} & \multirow{4}{*}{0.549} & Valid \\
\hline & WGC 2 & 0.851 & & & Valid \\
\hline & WGC 3 & 0.776 & & & Valid \\
\hline & WGC 4 & 0.420 & & & Valid \\
\hline
\end{tabular}

Source: Author's data processing and analysis 
Next, the authors conducts a discriminant validity test, the output of which is presented in table 3. A construct is deemed to pass the discriminant test if the cross loading value is greater than 0.7 in one variable. Meanwhile, indicators that have a value between 0.4 and 0.7 can still be accepted (Hartono \& Abdillah, 2015). In table 3, all of the indicators that have passed the discriminant validity test are shown.

The authors then tested the validity of formative construct. The parameter used to assess the validity of formative construct is VIF value $<$ 2,5 (Sholihin \& Ratmono, 2013). Result of the formative construct validity test in table 4 shows that all of the constructs have passed the test.

Table 3. Result of Discriminant Validity Test

\begin{tabular}{cccc}
\hline Variable & EW & WGC & Description \\
\hline EW1 & $\mathbf{0 . 7 8 0}$ & 0.449 & Valid \\
\hline EW2 & $\mathbf{0 . 8 1 3}$ & 0.467 & Valid \\
\hline EW3 & $\mathbf{0 . 8 7 4}$ & 0.386 & Valid \\
\hline WGC1 & 0.445 & $\mathbf{0 . 8 3 2}$ & Valid \\
\hline WGC2 & 0.500 & $\mathbf{0 . 8 5 1}$ & Valid \\
\hline WGC3 & 0.241 & $\mathbf{0 . 7 7 6}$ & Valid \\
\hline WGC4 & 0.308 & $\mathbf{0 . 4 2 0}$ & Valid \\
\hline
\end{tabular}

Source: Author's data processing and analysis

Further, the reliability test is also performed to establish consistency of the measurement tool in measuring a concept (Hartono \& Abdillah, 2015). The reliability test is done by examining two parameters, namely the Cronbach's alpha and composite reliability values. The rule applied based upon the statement of Hair et al. (2008) in Hartono and Abdillah (2015) is that the value of Cronbach's alpha or composite reliability is greater than 0.7. A Cronbach's alpha and composite reliability value of 0.6 is also still acceptable. Result of the reliability test is presented in table 5 .

As shown in table 5, Cronbach's Alpha and composite reliability value is above 0.7. As

\begin{tabular}{cccc} 
Table 4. Result of Formative Construct Validity Test \\
\hline Variabel & $\begin{array}{c}\text { Indica- } \\
\text { tor }\end{array}$ & VIF & $\begin{array}{c}\text { Descrip- } \\
\text { tion }\end{array}$ \\
\hline $\begin{array}{c}\text { Personal } \\
\text { Responsibility } \\
\text { (TP) }\end{array}$ & TP 1 & 1,238 & Valid \\
\cline { 2 - 4 } & TP 2 & 1,853 & Valid \\
\cline { 2 - 4 } & TP 3 & 1,713 & Valid \\
\hline $\begin{array}{c}\text { Personal Cost } \\
\text { (PC) }\end{array}$ & PC 1 2 & 1,293 & Valid \\
\cline { 2 - 4 } & PC 3 & 1,301 & Valid \\
\hline $\begin{array}{c}\text { Intention to } \\
\text { Blow the Whis- } \\
\text { tle (NW) }\end{array}$ & NW 1 & 1,207 & Valid \\
\cline { 2 - 4 } & NW 3 & 1,305 & Valid \\
\hline
\end{tabular}

Source: Author's data processing and analysis

Table 5. Result of Reliability Test

\begin{tabular}{cccc}
\hline Variable & $\begin{array}{c}\text { Composite } \\
\text { Reliability }\end{array}$ & $\begin{array}{c}\text { Cronbach's } \\
\text { Alpha }\end{array}$ & Remarks \\
\hline EW & 0,863 & 0,775 & Reliable \\
\hline WGC & 0,821 & 0,768 & Reliable \\
\hline
\end{tabular}

Source: Author's data processing and analysis

such, it can be concluded that the whole construct used in this study has passed the reliability test.

The author then conducted the hypotheses test. The test is done using a path coefficient score with $5 \%$ significance. For the $\mathrm{H}_{1}$ to $\mathrm{H}_{3}$ hypothesis, if t-statistics value $>1.64$ and coefficient direction is in line with the predetermined direction, then the hypothesis is accepted. If otherwise, the hypothesis is rejected. For hypothesis $\mathrm{H}_{4}$, if t-statistics value $>1.96$, the hypothesis is accepted. A summary of the result of the hypothesis test is presented in table 6 .

Based on table 6, the construct of personal responsibility affects positively to the intention of whistleblowing. Beta $(\beta)$ value is positive at 0.566 and t-statistics value of personal responsibility construct on the inten- 
Table 6. Result of Hypothesis Testing

\begin{tabular}{ccccc}
\hline Hypothesis & Construct & $\begin{array}{c}\text { Original } \\
\text { Sampel }\end{array}$ & T-statistic & Decision \\
\hline H1 & TP $\rightarrow$ NW & 0.566 & 5.398 & Accepted \\
\hline H2 & $\mathrm{PC} \rightarrow>$ NW & 0.112 & 1.139 & Rejected \\
\hline H3 & EW $\rightarrow$ NW & 0.060 & 0.448 & Rejected \\
\hline H4 & WGC $P C \rightarrow N W$ & -0.033 & 0.620 & Rejected \\
\hline
\end{tabular}

Source: Author's data processing and analysis

tion to blow the whistle is 5.398 or $>1.64$. Given such result, hypothesis 1 is accepted; personal responsibility does have a positive influence on the intent to do whistleblowing action. Personal cost construct has a negative effect on whistleblowing. Beta $(\beta)$ value is positive at 0.112 and T-statistics value of the personal cost construct on the intention to blow the whistle is 1.139 or $<1.64$. Given such result, hypothesis 2 is rejected; personal cost does not have an effect on the intention to do whistleblowing.

In line with the personal cost construct, the test result shows that the construct of education on whistleblowing has a positive effect on the intention to do whistleblowing. Based on table 6 , it can be seen that beta $(\beta)$ value is positive at 0.060 and t-statistic value of whistleblowing education construct is 0.448 or $<1.64$ and therefore hypothesis 3 is rejected. The result establishes that education on whistleblowing does not have an effect on the intention to blow the whistle.

Table 6 shows that beta $(\beta)$ value is negative at -0.033 and t-statistic value is 0.620 or $<1.96$. Based on the result, hypothesis 4 is rejected; reporting channel cannot moderate the influence of personal cost on the intention to blow the whistle.

\section{Personal Responsibility Has A Positive Effect On The Intention To Do Whis- tleblowing}

The variable of personal responsibility is empirically proven to positively affect the intention of civil servants to do whistleblow- ing. Result from this research is consistent with earlier researches by Curtis (2006), Robinson et al. (2012) and Alleyne et al. (2017). This indicates that personal responsibility is a factor that a person considers before blowing the whistle. The finding of this study supports the prosocial theory, which states that whistleblowing is a prosocial action that is a person's effort to help others accompanied by certain considerations.

Miceli et al. (2008) states that the possible diffusion effect of responsibility does not exist in whistleblowing cases. This is due to the fact that potential whistleblowers are not outsiders. They have sufficient time to consider the situation. This study indicates that civil servants working in the financial department of Banjarmasin Municipal Government Agencies and procurement working groups would be prone to do whistleblowing as they have a notion that they have a personal responsibility to contribute in the prevention of fraud in their working environment.

\section{Personal Cost Does Not Effect The Intention To Do Whistleblowing}

The personal cost variable is empirically proven to have no effect on a civil servant's intention to do whistleblowing. This means that personal cost is not a consideration for a potential whistleblower to report fraud. This finding does not accommodate the prosocial theory which states that a person essentially supports social interest, oftentimes with certain considerations including the benefit 
and risks, or which can also be referred to personal cost (Schultz et al., 1993).

Result of this study shows inconsistency with the research by Park et al. (2005), which found that personal cost is not an aspect considered when reporting a fraud. Park et al. (2005) assumes that based on the condition of the South Korean Government renowned for its corruption, civil servants who are respondents of the research would feel that retaliation targeted towards whistleblowers would be certain. As such, civil servants would tend to stay quiet as a result of having such view.

The author argues that social influence is large enough in framing a civil servant's behavior. This has been proven in the result of research conducted by Latan et al. (2018), which found that social group norms in Indonesia is still strong and thus affects the intention to do whistlebowing. Alleyne et al. (2013) states that the extent to which a person adopts a certain behavior depends on the inherent norms of the group where such person lives. This concept is founded upon the context of ethical decision making relating to subjective norms introduced by Ajzen (1991). Social influences such as group norms may shape a person's perception of the severity of the violation being observed (Hooks et al., 1994) as it is capable of conveying a logic thought whether or not to blow the whistle.

Additionally, power distance that probably remains high within government organizations have contributed to this inconsistency of result. Hofstede (1980) sets forth that power distance imply inequality. Research conducted by The Hofstede-Insights (2018) found that Indonesia still scores high in terms of power distance.

Tsui and Windsor (2001) states that the higher the power distance is in a country, the higher the tolerance level to unethical business practices. Power distance makes it necessary for certain boundaries to be applied in dealing with the public, including within the organization. Referring to the organizational context, subordinates tend to readily obey orders from a superior despite wanting to refuse. This is also believed to occur in the whistleblowing context. Terzi (2011) finds that whistleblowing is an action seldom adopted in environments where power distance is high. This is due to the fact that whistleblowing can create tension within the organization (Mitchell \& Sikka, 2004). Alleyne et al. (2013) stipulates that society with a high power distance tend to value a person based on wealth, status and power, even if such attributes are gained through actions that are not ethical. This is often used by civil servants to justify their tolerance of fraud and lack of courage to report fraudulent acts.

\section{Education Does Not Effect on Intention To Do Whistlebowing}

Education on whistleblowing has no effect on the intention of a civil servant to report fraud. Those research result is not consistent with an earlier study conducted by Cho and Song (2015), which states that the existence of education on whistleblowing is believed to be able to increase a person's tendencies to do whistlebowing. Result of this research does not support the social learning theory, which supposes that a person learns through observation and direct experience, which ultimately would affect their behavior.

The gap between the result of this research and the earlier studies is also indicated to be the caused by the fact that education relating to whistleblowing, whether with regard to the urgency to become a whistleblower, whistleblowing system, recognition given to whistleblowers, until the probability to follow up from fraud reported is still low. 
The argument is sustained by descriptive statistical evidence (in Appendix 1), showing that almost half of the respondents are still doubtful and only somewhat agree that the organization where they work provides education to civil servants the presence of anonymous reporting channel. This might serve as one of several factors that render education still unable to positively affect a civil servant's intention to do whistlebowing.

Young (2017) tested the influence of the presence of education as represented by persuasive messages to bring a change of behavior among individuals from remaining passive to having the courage to to do whistlebowing. Result of such research shows that persuasive messages are indeed capable of changing the behavior of individuals from being an observer to become a whistleblower. However, this condition is prominent only among employees who are familiar with non-ethical, improper, or even fraudulent conduct in the organization.

Considerations and assessment of personal factors of the individuals within an organization prior to education should also be taken into account in efforts to encourage these individuals to do whistlebowing. This is because organizations play an urgent role in framing belief and developing resilience of their employees to commit to doing what they consider as morally right (Sekerka, Bagozzi \& Charnigo, 2009). Mannion and Davis (2015) states that it would be very naïve to assume that all potential whistleblowers need to be fully motivated only with a matter of conscience. Many of them may also be motivated by personal perception problem, such as work related grievances and personality conflicts. This emphasizes that understanding the characteristics of individuals in organizations is an aspect that needs to be prioritized in understanding the reasons that drive individuals to be willing to report fraud before focusing on education in general.

\section{Reporting Channel Does Not Moderate The Influence of Personal Cost On Intention To Do Whistlebowing}

Result from the testing of the moderation effect of reporting channel shows that reporting channel is not capable of moderating personal cost on the intention to do whistlebowing. The result of the present research differs from that of an earlier study by Gao et al. (2015), which stipulated that reporting channel is able to serve as a predictor variable of moderation. The result is also inconsistent with the theory of utilitarian ethics, which states that a person who desires to undertake political action such as whistleblowing will be seriously evaluating the best choices to be able to avoid fatal consequences for him or herself or any related party.

Kaplan et al. (2012) conducted a research relating to the effect of reporting channel in enhancing intention to report fraud. Kaplan et al. (2012) found that availability of internal reporting channels may augment an intention to report fraud relatively if compared to the treatment received previously by the whistleblower only if experience shows that there is no retaliation directed towards the whistleblower. This means that a bad experience of a whistleblower in the past will serve as a restraint to a potential whistleblower's effort to report a fraud, thus reporting channel has no effect in weakening the effect of personal cost within a whistleblower.

Hakim (2017) also proved that reporting channel is not capable of moderating the influence of personal cost on the intention of tax office employees to report fraud. This is due to the fact that rules on whistleblowing that apply at the Directorate General of Tax 
lacks elaboration in explaining the level of security and certainty on follow up actions. This lack of information would ultimately prevent the obtainment of a full understanding by the respondents of the characteristics of the available reporting channels.

Berry (2004) states that there are other factors that influences the decision made by a potential whistleblower to report fraud in addition to the availability of reporting channel, both of which still have some significant risks. The presence of a staff rotation system in the government is believed to be another reason why reporting channels do not serve to moderate the effect of personal cost on the intention to do whistlebowing. Staff rotation is regulated by Government Regulation Number 11 of 2017 on Civil Service Management as a means to acquire a dynamic workforce in terms of talent mapping, succession and career planning. However, the staff rotation system has had a boomerang effect as civil servants assume that there is a high probability that he or she will have to work with the person whom they have reported. If the perpetrator being reported is a current coworker within the same regional government agency, there is a possibility that that person will at some point in the future become a supervisor or occupies an important function within another unit (such as the Inspectorate) and may obstruct the whistleblower's work as part of retaliation. As such, personal cost is deemed to be an unavoidable consequence if one intends to report a fraud within the government (Park et al., 2005).

Consistent with the descriptive statistics (Appendix 2), lack of information relating to the available whistleblowing channel, such as on safety assurances and possible follow up action taken, has been the cause for civil servant not receiving adequate information to make informed decisions in using the reporting/whistleblowing channel to report fraud. Result of the descriptive statistics of the anonymous whistleblowing channel indicator is also low. This shows that available whistleblowing channels is still not capable of strengthening civil servants' intention to report fraud. Indeed, thus far the reality is that elaboration of the relevant regulations into the technical details of the fraud reporting system, both the internal and the anonymous systems, is yet to be intensively conducted to civil servants in Banjarmasin Municipal.

Nayir and Herzig (2012) affirms that one should not forget that whistleblowing is complex action and involves a process. Available whistleblowing channels cannot serve as a sole stimulus without taking into account other aspects. Karatuna and Basol (2018) states that the process can be mediated by establishing satisfaction in communication between subordinates and supervisors, thus ultimately achieving synergy. This finding shows that civil servants have evaluated that the whistleblowing channel applied in the Banjarmasin municipal government, both through its internal as well as anonymous reporting systems, is still not able to reduce risks that arise to an individual when reporting fraud.

\section{CONCLUSION}

Based on the results generated by this study, it can be concluded that personal responsibility is an aspect taken into consideration by the civil servants of the Banjarmasin Municipal Government before reporting a fraud. When a civil servant realizes that whistleblowing is a personal responsibility, he or she will be more motivated to undertake such course of action. In addition, personal cost is a factor 
that is not taken into account by respondents when they intend to report fraud. This is due to the existence of the effect of social norms that can alter a civil servant's view point with regard to whistleblowing, and the tendency of civil servants to play it safe and obey their supervisors (power distance).

Education has not been able to affect the intention of civil servants to report fraud. This is suspected of being caused by the lack of education and dissemination. Whistleblowing channel is also unable to moderate the effect of personal cost on the intention to do whistlebowing. The staff rotation system adopted by the government give rise to the perception of assured retaliation as a result of the whistleblowing action, and thus even when an anonymous reporting channel has been established, civil servants would tend to remain quiet.

The study is limited in terms of response rate, which has been less optimal that expected by the authors in order to cover all respondents through a census method (saturated sampling). The further authors need to consider the most appropriate time for the research, particularly as the research studied objects that have similar characteristics. The research further also can improve the research models by considering the addition of other variables that are believed to influence a person's intention to do whistlebowing, such as type of personality, religiosity, or commitment of the organization. The study is also impeded in its quantitative approach. The further research can implement a qualitative approach using questionnaires containing open-ended questions or interviews to explore in more detail the reasons for a civil servant to engage or not to engage in whistleblowing activity.

The study indicates a theoretical implication that the application of the prosocial theory has been proven in this study, while studies on social learning and utilitarian ethics theories needs to be repeated. The result provides a description of the factors that affect civil servants' intention to blow the whistle. In terms of practice, findings from this study implies that a civil servant should well understand his or her role in safeguarding the organization from fraud that can have a detrimental effect. Civil servants are expected to maintain their commitment to be continually aware of their environment, especially relating to actions that may constitute fraud.

The result of this study can serve as consideration for the government, both at the national and local level, to increasingly promote policies that can enhance government employee's intention to report fraud. This study shows that the role of personal responsibility of civil servant to prevent fraud is a driving force for whistleblowing. This means that the emphasis of a civil servant's role within the organization should not only be confined to the fulfillment of his or her normal work but also in preventing fraud is important to be applied. This can be manifested through intensive dissemination and the design of a whistleblowing program that take into account the definition of civil servants' responsibilities at the work place.

\section{REFERENCES}

ACFE. (2016). Survai Fraud Indonesia 2016. Retrieved from https://acfeindonesia.or.id/survei-fraudindonesia/. Maret 2018.

Ajzen, I. (1991). The theory of planned behavior. Organizational Behaviour and Human Decision Process, 50, 179-211. 
Alleyne, P., Hudaib, M., \& Pike, R. (2013). Toward a conceptual model of whistle -blowing intentions among external auditors. The British Accounting Review, 45, 10-23.

Alleyne, P., Soverall, W. C, Broome, T., \& Pierce, A. (2017). Perceptions, predictors and consequences of whistleblowing among accounting employees in Barbados. Meditary Accountancy Research, 25(2), 241267.

Andrade, J. A. (2015). Reconceptualising Whistleblowing in a Complex World. Journal of Business Ethics, 128, 321335 .

Arikunto, S. (2012). Prosedur Penelitian Suatu Pendekatan Praktek. Jakarta: Rineka Cipta.

Ayers, S., \& Kaplan, S. E. (2005). Wrongdoing by Consultants: An Examination of Employees' Reporting Intentions. Journal of Business Ethics, 57, 121-137.

Bandura, A. (1971). Social Learning Theory. New York: General Learning Press.

Basri, S. A., Marsam, A. D., Majid, R. A., Abu, N. A., \& Mohamed, N. (2017). Reinforcement tool of whistleblowing to eradicate fraud in public sector. SHS Web of Conference, 36, 1-6.

Batson, C. D. (2011). A history of prosocial behavior research. Handbook of the History of Social Psychology. Routledge.

Berry, B. (2004). Organizational culture: a framework and strategies for facilitating employee whistleblowing. Employee Responsibilities and Rights Journal, 16(1), 1-11.

Bhal, K. T., \& Dadhich, A. (2011). Impact of ethical leadership and leadermember exchange on whistleblowing:
The moderating impact of the moral intensity of the issue. Jourmal of Business Ethics, 103, 485-496.

Brewer, G. A., \& Selden, S. C. (1998). Whistle blowers in the federal civil service: New evidence of the public service ethic. Journal of Public Administration Research and Theory, 8, 413-440.

Caillier, J. G. (2017). An examination of the role whistle-blowing education plays in the whistle-blowing process. The Social Science Journal, 54, 4-12.

Cavanagh, G. F., Moberg, D. J. \& Velasquez, M. (1981). The ethics of organizational politics. Academy of Management Review, 6(3), 363-374.

Cho, Y. J., \& Song, H. J. (2015). Determinants of whistleblowing within government agencies. Public Personnel Management, 44(4), 450472.

Curtis, M. B., (2006). Are audit-related ethical decisions dependent upon mood?. Journal of Business Ethics, 68(2), 191-209.

Chiu, R. K. (2002). Ethical judgment, locus of control, and whistleblowing intention: A case study of Mainland Chinese MBA students. Journal of Business Ethics, 43(1), 65-74.

Dozier, J. B., \& Miceli, M. P. (1985). Potential predictors of whistleblowing: A prosocial behavior perspective. Academy of Management Review, 10(4), 823-836.

Eisenberg, N., \& Mussen, P. H. (1989). The Roots of Prosocial Behavior in Children. Britania Raya: Cambridge University Press.

Frisque, D., \& Kolb, J. (2008). The effects of an ethics training program on attitude, knowledge, and transfer of 
training of office professional: A treatment and control-group design. Human Resource Development Quarterly, 19, 35-53.

Gao, J., Greenberg, R., \& Wong-On-Wing, B. (2015). Whistleblowing intentions of lower-level employees: The effect of reporting channel, bystanders, and wrongdoer power status. Journal of Business Ethics, 126, 85-99.

Gao, L., \& Brink, A. G. (2017). Whistleblowing studies in accounting research: A review of experimental studies on the determinants of whistleblowing. Journal of Accounting Literature, 38, 1-13.

Government Regulation Number 11 of 2017 on Civil Service Management.

Ghani, N. A., Galbreath, J., \& Evans, R. (2013). Predicting whistle-blowing intention among supervisors in Malaysia. Journal of Global Management, 3(1), 1-18.

Graham, J. W. (1986). Principled organizational dissent: a theoretical essay. In B. M. Staw, \& L. L. Cummings (Eds.), Research in organizational behaviour, 8, 1-52. Greenwich, CT: JAI.

Hakim, T. I. R (2017). Pengaruh faktorfaktor multidimensional terhadap niat melakukan whistleblowing dengan whistleblowing channel sebagai variabel moderasi (Studi pada KPP pratama Malang Utara dan Kepanjen). (Tesis) Program Magister Akuntansi Universitas Brawijaya, Malang.

Hartono, J., \& Abdillah, W. (2015). Partial Least Square (PLS) alternatif Structural Equation Modelling (SEM) dalam Penelitian Bisnis. Yogyakarta: Penerbit Andi.
Hersh, M. A. (2002). Whistleblowersheroes or traitors?: Individual et allective responsibility for ethical behaviour. Annual Reviews in Control, 26, 243-262.

Hofstede, G. (1980). Culture's consequences: International differences in workrelated values. California: Sage Publication.

Hooks, K. L., Kaplan, S. E., \& Schultz Jnr, J. J. (1994). Enhancing communication to assist in fraud prevention and detection. Auditing: A Journal of Practice \& Theory, 13(2), 86-117.

Iskandar, A., \& Saragih, R. (2018). Pengaruh sikap ke arah perilaku, norma subjektif dan persepsi kontrol atas perilaku terhadap niat dan perilaku whistleblowing CPNS. Jurnal Tata Kelola dan Akuntabilitas Keuangan Negara, 4(1), 63-84.

Jarvis, P., Holford, J. \& Griffin, C. (2003). The theory and practice of learning. Second edition. Great Britain and United States: Kogan Page Limited.

Kaplan, S. E., Pany, K., Samuels, J., \& Zhang, J. (2012). An examination of anonymous and non anonymous fraud reporting channels. Advances in Accounting, 28(1), 88-95. doi: 10.1016/j.adiac.2012.02.008.

Kaplan, S. E., \& Whitecotton, S. M. (2001). An examination of auditors' reporting Intentions when another auditor is offered client employement. Auditing Journal of Practice \& Theory, 2O(1), 45-63. doi: 10.2308/aud.2001.20.1. 45 .

Karatuna, I., \& Basol, O. (2018). To blow the whistle or not: The roles of perceived organizational retaliation and upward communication satisfaction in employee responses to observes wrongdoing. Redefining Corporate 
Social Responsibility, 13, 217-233.

Kuncara, A., Furqorina, R., \& Payamta. (2017). Determinants of internal whistleblowing intentions in public sector: Evidence from Indonesia. SHS Web of Conference, 34, 1-9. doi: doi.org/10.1051/shsconf/ 20173401002.

Latan, H., Ringle, C. M., \& Jabbour, C. J. C. (2018). Whistleblowing intention among public accountants in Indonesia: Testing for the moderation effects. Journal of Business Ethics, 152(2), 573-588.

Leeds, R. (1963). Altruism and the norm of giving. Merrill-Palmer Quarterly of Behavior and Development, 9(3), 229-240.

Mannion, R., \& Davies, H. T. (2015). Cultures of silence and cultures of voice: The role of whistleblowing in healthcare organisations. International Journal Health Policy Management, 4(8), 503-505.

Meikhati, E., \& Rahayu, I. (2015). Peranan audit internal dan pencegahan fraud dalam menunjang efektivitas pengendalian internal (studi kasus pada Yayasan Internusa Surakarta). Jurnal Paradigma, 13(1), 77-91.

Meng, T. P., \& Fook, O. S. (2011). Comparative analysis of whistleblower protection legislations in England, USA and Malaysia. African Journal of Business Management, 5(27), 11246-11255. doi: 10.5897/AJBM11.1332.

Mesmer-Magnus, J. R., \& Viswesvaran, C. (2005). Whistleblowing in organizations: an examination of correlates of whistleblowing intentions, actions and retaliation. Journal of Business Ethics, 62(3), 277-297.
Miceli, M. P., \& Near, J. P. (1985). Characteristics of organizational climate and perceived wrongdoing associated with whistleblowing decisions. Personnel Psycology, 38, 525-544. doi: 10.1111/j.17446570.1985.tboo558.x.

Miceli, M. P., Near, J. P., \& Dworkin, T. M. (2008). Whistleblowing in organizations. New York, NY: Routledge.

Miceli, M. P., Near, J. P., \& Schwenk, C. R. (1991). Who blows the whistle and why?. Industrial and Labor Relations Review, 45(1), 113-130.

Mitchell, A., \& Sikka, P. (2004). Accountability of the accounting bodies: the peculiarities of a British accountancy body. British Accounting Review, 36, 395-414.

Nayir, D. Z., \& Herzig, C. (2012). Value orientations as determinants of preference for external and anonymous whistleblowing. Journal of Business Ethics, 107(2), 197-213.

Near, J. P., \& Miceli, M. (2016). After the wrongdoing: What managers should know about whistleblowing. Business Horizons, 59(1), 105-114. doi: 10.1016/j.bushor.2015.09.007.

Nurhidayat, I., \& Kusumasari, B. (2018). Strengthening the effectiveness of whistleblowing system: A study for the implementation of anticorruption policy in Indonesia. Journal of Financial Crime, 25(1), 140-154.

Park, H., Rehg, M. T., \& Lee, D. (2005). The influence of Confucian ethics et allectivism on whistleblowing intentions: A study of South Korean public employees. Journal of Business Ethics, 58(4), 387-403. 
Park, H., Blenkinsopp, J., Oktem, M. K., \& Omurgonulsen, U. (2008). Cultural orientation and attitudes toward different forms of whistleblowing: A comparison of South Korea, Turkey, and the U.K. Journal of Business Ethics, 82(4), 929-939.

Robinson, S. N, Robertson, J. C., \& Curtis, M. B. (2012). The effects of contextual and wrongdoing attributes on organizational employees' whistleblowing intentions following fraud. Journal of Business Ethics, 106(2), 213-227.

Schultz, J. J., Johnson, D. A., Morris, D., \& Dyrnes, S. (1993). An investigation of the reporting of questionable acts in an international setting. Journal of Accounting Research, 31, 75-103. doi: 10.2307/2491165.

Sekerka, L. E., Bagozzi, R., \& Charnigo, R. (2009). Facing ethical challenges in the workplace: Conceptualizing and measuring professional moral courage. Journal of Business Ethics, $89(4), 565-579$

Semendawai, A. H., Santoso, F., Wagiman, W., Omas, B. I., Susilaningtias, Wiryawan, S. M. (2011). Memahami whistleblower. Jakarta Pusat: Lembaga Perlindungan Saksi dan Korban (LPSK).

Septianti, W. (2013). Pengaruh faktor organisasional, individual, situasional, dan demografis terhadap niat melakukan whistleblowing internal. Simposium Nasional Akuntansi XVI, Manado.

Sheler, J. L. (1981). When employees squeal on fellow workers. US News \& World Report, 16, 81-82.

Sholihin, M., \& Ratmono, D. (2013). Analisis SEM-PLS dengan WarpPLS 3.o. Yogyakarta: Penerbit Andi.
Sina, L. (2008). Dampak dan upaya pemberantasan serta pengawasan korupsi di Indonesia. Jurnal Hukum Pro Justitia, 26(1), 39-51

Stead, W. E., Worrell, D. L., \& Stead, J. G. (1990). An integrative model for understanding and managing ethical behavior in business organizations. Journal of Business Ethics, 9(3), 233242.

Suratno. (2017). Perlindungan hukum Saksi dan korban sebagai whistleblower dan justice collaborators pada pengungkapan kasus korupsi berbasis nilai keadilan. Jurnal Pembaharuan Hukum, 4(1), 130-139.

Terzi, A. R. (2011), Relationship between power distance and autocratic democratic tendencies. Educational Research and Reviews, 6(7), 528535 .

The Hofstede-Insights. (2018). Country comparison. Retrieved from https:// www.hofstede-insights.com/countrycomparison/indonesia/.

Transparancy International. (2016). Corruption Perception Index. Retrieved from https://ti.or.id/wpcontent/uploads/2017/04/ corruption perception index 2016 design. pdf-2.pdf.

Tsui, J., \& Windsor, C. (2001). Some crosscultural evidence on ethical Reasoning. Journal of Business Ethics, 31(2), 143-150.

Widyastuti, A. R. (2015). Disfungsional birokrasi sebagai kendala dalam pemberantasan korupsi. Yustisia, 4 (3), 108-117.

Young, R. F. (2017). Blowing the whistle: Individual persuasion under perceived threat of retaliation. Behavioral Research in Accounting, 
29(2), 97-111.

Zhuang, J. (2003). Whistle-blowing and peer reporting: A cross-cultural comparison of Canadians and Chinese. (Thesis). Magister Ilmu Manajemen, Universitas Lethbridge, Alberta, Kanada.

\section{ACKNOWLEDGEMENT}

The author whishes to express the highest gratitude and appreciation to the Banjarmasin Municipal Government, in particular to (1) Unified Nation and Politics Agency
(Badan Kesatuan Bangsa dan Politik) that has assisted in the administrative process and directed the author to the desired respondents, (2) respondents of the research, who are civil servants of the financial department of all regional government units and Procurement Services Units (ULP) within the Banjarmasin Municipal Government, who have set aside time to complete the questionnaire, and (3) other persons whom the author cannot individually mention.

\section{APPENDICES}

Appendix 1. Descriptive Statistics of Education Variable on Whistleblowing

\begin{tabular}{|c|c|c|c|c|c|c|c|c|c|}
\hline \multirow{2}{*}{ Item } & \multicolumn{7}{|c|}{ Frequency of Answers } & \multirow{2}{*}{ Mean } & \multirow{2}{*}{$\begin{array}{l}\text { Deviation } \\
\text { Standard }\end{array}$} \\
\hline & STS (1) & TS (2) & ATS (3) & $N(4)$ & AS (5) & $S(6)$ & SS (7) & & \\
\hline EW1 & 0 & 0 & 0 & 5,77 & 20,19 & 60,58 & 13,46 & 5,82 & 0,73 \\
\hline EW2 & 0 & 0 & 0 & 17,31 & 31,73 & 39,42 & 11,53 & 5,45 & 0,91 \\
\hline EW3 & 0 & 2,88 & 2,88 & 14,42 & 25 & 39,42 & 15,38 & 5,41 & 1,17 \\
\hline
\end{tabular}

Source: Author's data processing and analysis

Appendix 2. Descriptive Statistics of Reporting Channel Variable

\begin{tabular}{|c|c|c|c|c|c|c|c|c|c|}
\hline \multirow{2}{*}{ Item } & \multicolumn{7}{|c|}{ Frequency of Answers } & \multirow{2}{*}{ Mean } & \multirow{2}{*}{$\begin{array}{l}\text { Deviation } \\
\text { Standard }\end{array}$} \\
\hline & STS (1) & TS (2) & ATS (3) & $N(4)$ & AS (5) & $S(6)$ & SS (7) & & \\
\hline SP1 & 0 & 0 & 0 & 15,38 & 30,77 & 47,11 & 6,73 & 5,45 & 0,83 \\
\hline $\mathrm{SP} 2$ & 0 & 0 & 0 & 5,77 & 21,15 & 56,73 & 16,35 & 5,83 & 0,76 \\
\hline SP3 & 0 & 0 & 0,96 & 4,81 & 26,92 & 50 & 17,31 & 5,78 & 0,82 \\
\hline SP4 & 0 & 2,88 & 10,57 & 24,04 & 19,23 & 29,80 & 13,46 & 5,03 & 1,33 \\
\hline SP5 & 0 & 0 & 10,57 & 24,04 & 20,19 & 28,84 & 16,35 & 5,16 & 1,26 \\
\hline
\end{tabular}

Source: Author's data processing and analysis 


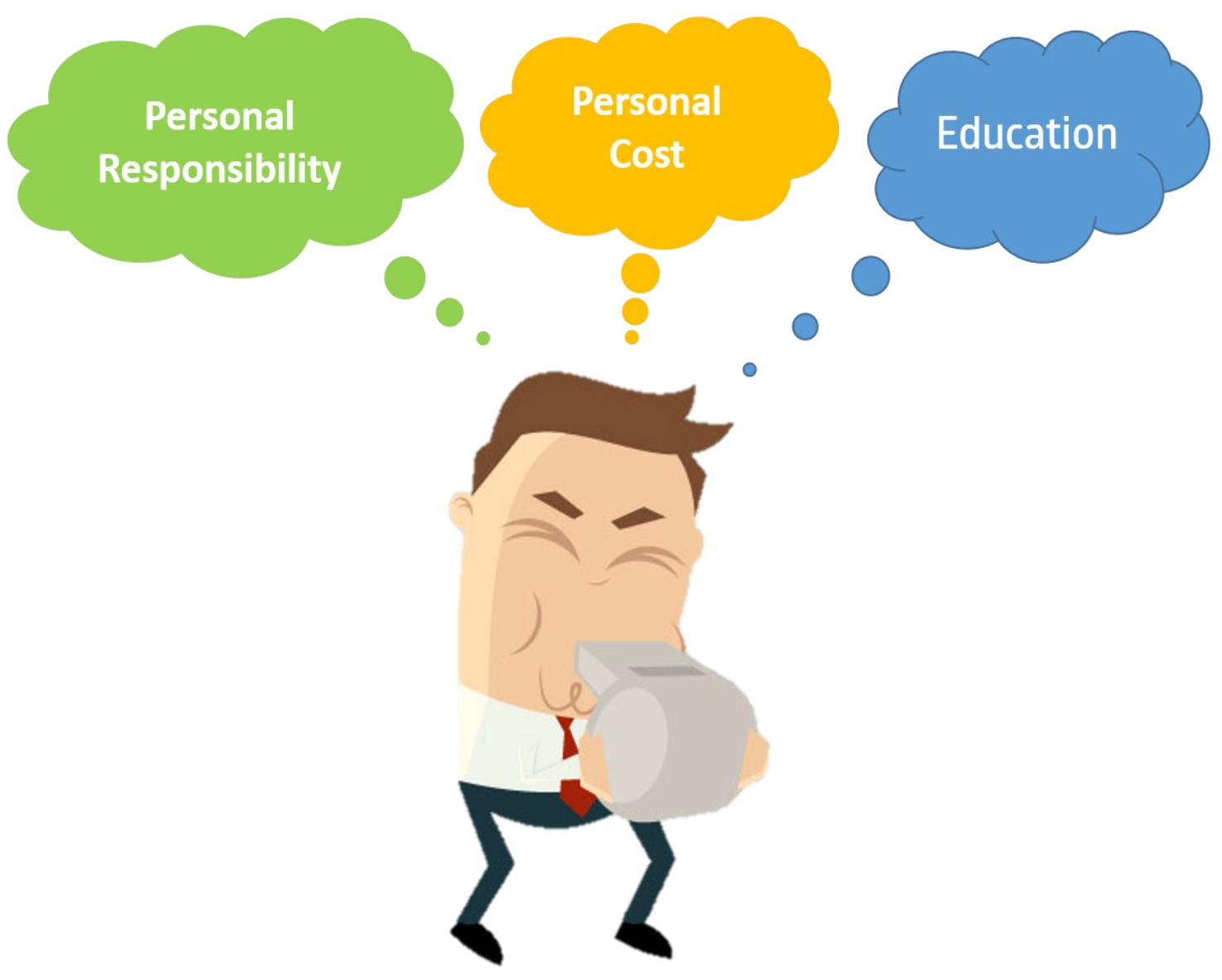

